\title{
Demodicidiasis and Leprosy
}

\section{(Review and Proposal)}

\author{
W M B. NUTTING, PH.D. \\ University of Massachusetts, Amherst, Mass. \\ WALDEMAR F. KIRGHHEIMER, M.D., PH.D. \\ U.S.P.H.S. Hospital, Carville, La. \\ ROY E. PFALTZGRAFF, M.D.* \\ Adamawa Provincial Leprosarium, Nigeria, West Africa
}

Despite a wealth of speculation there is no proof that any arthropod serves as transmission agent for human leprosy (Dungal, ig6i). As a suspect vector the acarine Demodex folliculorum is in some respects unique since it is (I) apparently ubiquitous with an incidence of I oo per cent (Fuss, I 933), (2) found in intimate association with Mycobacterium leprae in the skin complex (Borrel, I 9o8), and (3) probably passed from mother to young during the nursing process. Furthermore, Spickett (I96Ib) reported the presence of acid-fast bacteria in the gut of $D$. folliculorum and that the gut contents of the mite can be regurgitated. These observations point up the need for continuing re-evaluation and for further studies on the possible causal relationship between demodicidiasis and leprosy.

The present paper represents an attempt to examine all facets of our knowledge of the association of $D$. folliculorum and leprosy, to present information on the biology of other demodicids pertinent to an evaluation of this relationship, and to indicate a programme of study which could materially advance our understanding of the role, if any, of demodicidiasis in the initiation of leprosy.

\section{Demodex folliculorum}

Borrel ( I go8) was apparently the first to suggest an association between $D$. folliculorum and $M$. leprae. He found, in sections of skin from leprosy patients, that the bacteria were investing, i.e. closely surrounding, the mite (rgoga). From this he speculated (igogb, p. i 26) 'Le transport et l'inoculation dans le système pilaire peut certainement se faire au moment de la migration des parasites d'un nez lépreux à un nez sain.' He suggested ( I gogc) that Demodex as it fed on sebum could take up the bacillus and so transfer the organism to another host. His reports thus associated demodicid mites with sebaceous gland activity and leprosy transmission.

In some respects as pointed out by Spickett (I96Ib) the careful work of Gmeiner (I9o8) retarded investigation based upon the speculations of Borrel. He reported that in twelve different skin diseases demodicids were no more common than in normal skin. On this basis and from examination of skin sections which showed no inflammatory reaction associated with $D$. folliculorum he concluded that this demodicid was non-pathogenic (see Beerman and Stokes, I 934) and held no causal or cooperative position with respect to any disease. In a later paper ( I 909), however, Gmeiner discussed a consistent relationship in red mange of dogs wherein $D$. canis is associated with Staphylococcus albus. He stated that here the demodicids had prepared the way for the bacterial infection. He assumed that a like situation may well prevail in blepharitis associated with $D$. folliculorum. The analogy here with $M$. leprae is obvious and had this latter work been better known it undoubtedly would have served as a spur to leprosy-demodicid studies.

In i9 Io LeFebvre, familiar with the work of Borrel, reported on studies of leprosy and $D$. folliculorum. He found a 25 per cent incidence of this mite in his examination of I oo patients with leprosy. He stated that this figure was nearly identical to that obtained from an examination of 'healthy' individuals. Although he found both the mite and $M$. leprae in the same hair follicle he could not find bacilli within the mites. He noted that demodicids are not found on the

\footnotetext{
*Former Chief, Rehabilitation Branch, U.S.P.H.S.
} Hospital, Carville, La. 
appendages of man, a predilection site for leprosy [sic], and also that in his studies no children were Demodex positive. His conclusion was that $D$. folliculorum was not a likely transfer agent of leprosy.

The work of Bertarelli and Paranhos (I9Io) was based also on the findings and speculations of Borrel. They examined 6o patients from the leprosarium at Guapira. According to their report only 15 of these [only 59 listed!] were positive for $D$. folliculorum. Furthermore, in their sample patients with abundant 'comedoni' (indicative of involvement and hyperactivity of the sebaceous glands) were rarely positive for Demodex (only 3 of the 59). They stated that many leprosy cases with advanced facial lesions had an abundance of the mite. This led them to the interesting idea that Demodex is a secondary invader of an area in which skin defences had been reduced by the leprosy bacillus. In a remark unfortunately not documented by data they noted that demodicids are scarce in negroes even though facial lesions of leprosy were present. Bertarelli and Paranhos concluded that their study gave no information in favour of the transmission of leprosy by Demodex.

Majocchi (I9I4) reported on some observations similar to those of Borrel. He suggested that the fusion of leprous nodules was responsible for placing the leprosy bacteria in contiguity with D. folliculorum. These last could then spread the disease either over the body of the infected host or to healthy individuals.

In two papers A. Serra (I9I2, I92 I) reported the results of his examination of patients with leprosy for $D$. folliculorum. In brief his data show 32 of 80 positive for $D$. folliculorum. He found a higher incidence in 'tuberculoid' and 'mixed' (63+ per cent) when compared to 'anaesthetic' leprosy $(36+$ per cent $)$. This mite abundance does, however, seem to correlate not so much with the kind of leprosy but rather with the presence or absence of comedones. His figures (I92 I) show that of 28 patients with abundant comedones 22 (or 78 per cent) were Demodex positive. Also in his study of 192 I he found I 5 of $5^{8}$ patients with Demodex and bacilli together in the examination samples. Serra smeared a mixture of Demodex and leprosy bacilli on a patient assessed negative for both but showing symptoms of 'anaesthetic' leprosy. Mites and bacilli were recovered in two months. $\mathrm{He}$ also experimented with applications of like material on dogs (no positive results) and inoculated a glucose preparation of the same material into the anterior chamber of the eye in rabbits (negative results). His attempts at demonstrating Demodex and bacilli in the hair follicle of man or bacilli in Demodex failed. Serra notes the difficulty of establishing Demodex as a vector if the bacilli are rarely found within the hair follicle or sebaceous gland. He also suggests that Demodex could produce an irritant which would induce mobile elements of the connective tissue to act as mediators between mite and bacilli.

In assessing the value of all of these survey accounts (Borrel through Serra) one should bear in mind that Gmeiner (I go8) found normal people 97 per cent positive for Demodex. It is also true as noted by Serra (I92I), and others since his report, that mites may readily be missed on one examination; subsequent study will often reveal their presence.

Since the work of Serra (I92I), with the exception of Spickett (below), accounts of the Demodex-leprosy problem are either text-book allusions (e.g. Neveau-Lemaire, I93

papers commenting on the work of Borrel, Majocchi, or LeFebvre (e.g., Hirst, i9i9; Dungal, ig6r).

Included in his review of the possibility that D. folliculorum is a vector of leprosy bacilli Spickett ( 196 I b) reported the following information:

I. D. folliculorum will ingest minute bits of plastic and resin.

2. These ingested particles are regurgitated by the mite.

3. Acid-fast bacteria are occasionally (in two ovigerous females) found in the gut of $D$. folliculorum.

4. D. folliculorum does penetrate the sebaceous gland to the dermis.

$\mathrm{He}$ also suggested that $D$. folliculorum might transport bacteria between hair follicles. This, however, is open to question since Spickett's assumption is based on very circumstantial evidence (Spickett, ig6ra) that ovigerous females must have recently entered a hair follicle. This is certainly not assured as is indicated by such studies as Nicholas (1943) who 
found large numbers of $D$. folliculorum in hypertrophied sebaceous glands and from studies of other demodicids as D. caprae where marked populations build up in one locale. There is certainly the added possibility that the bacteria within the mites as reported by Spickett were obtained from within the same hair follicle.

Spickett's (rg6ra) account of the biology of $D$. folliculorum which might be useful to studies of the Demodex-leprosy relationship does not take into account many interesting observations in older publications. Fuss (1933) in a very careful study of $\mathrm{IO}_{4}$ individuals in age groups from children to 70 years found Ioo per cent infestation with $D$. folliculorum. This mite has been found in man from all major areas of the world and in Caucasoid, Negroid and Mongoloid races (see LeFebvre, I9ı; Yokayama, I94I; G. Serra, I 942). Demodex would, therefore, seem to qualify under Spickett's criteria that a transfer agent be ubiquitous, and be found in areas endemic for leprosy.

Hirst, in I9I9, provided excellent figures to show that the mouth parts of $D$. folliculorum are stylet-like chelicerae admirably suited to cell penetration. He also noted the absence of an anus and the sac-like nature of the digestive tract. These two features plus the obvious undercutting and destruction of cells by this and other species led Nutting and Rauch (1963) to contend that all demodicids are primarily cell feeders. The implication or statement that $D$. folliculorum feeds only on sebum (Gmeiner, I 9o8; Spickett, I96 гa - although revised I96 Ib) would appear unfounded. Several accounts are in existence of the occurrence of $D$. folliculorum in loci other than sebaceous glands (see Nutting, I965). It has been noted (Nutting, i 964) that because of its low nitrogen content sebum is an unlikely product to sustain mite development.

It should be further borne in mind that the details of the life cycle of $D$. folliculorum (Spickett, I96Ia) are based on short-term in vitro studies $(6+$ days on sebum $)$ coupled with limited and circumstantial in vivo evidence. We need confirmation of the suggested mechanism and stage of transference (direct contact during the nymphal stage?), span of the life cycle ( $14 \frac{1}{2}$ days?), and movement between hair follicles (adults or nymphal stage?) as postulated by Spickett. As yet no complete study of the anatomy of any demodicid has been published although certain systems and a review account of our current position in this regard may be found in Nutting, I 950 and Nutting, I 964 .

To date no attempt has been made to examine critically the physiology of any demodicid. Spickett ( 1 $9^{6}$ r a) using $D$. folliculorum maintained on sebum or lanolin reported negative phototaxy for all stages, positive stereotaxy for larvae, protonymphs, and females with shifting stereotaxy for deutonymphs and males, no reaction in any stage to gravity, and that larvae feed continuously, males rarely and deutonymphs not at all. Although no survival studies for this species have been attempted Daniel et al. (I 959) did find one mite viable in dry cerumen after four months.

Until we have more secure observational or experimental information on the biology of $D$. folliculorum we are in a weak position to assess the Demodex-leprosy problem.

Demodicids would seem to have access to $M$. leprae in the lumina of the hair follicles or sebaceous canals or even from within the cells of the pilo-sebaceous complex. They would, furthermore, appear capable of opening the pilo-sebaceous apparatus both by enlargement of the canals (distension and undercutting) and by actual penetration of the cells. Bacteria could be held in the sac-like gut and upon regurgitation or on death of the mite be liberated to the host tissue. In this last circumstance the problem of elimination from the exoskeleton is discussed below. Unlike many arthropods, demodicid salivary glands are solid (holocrine) cell masses (Nutting, unpublished) so that here only the hollow salivary duct could house bacteria unless these are able to survive intracellularly in the mite tissues.

Entry of $M$. leprae bacilli to the host cells from $D$. folliculorum could conceivably come about not only through regurgitation but also through phagocytosis of the infected mites by mesodermal giant cells (see Nutting and Beerman, I965). Khanolkar ( I959) has noted that $M$. leprae multiplies within phagocytic monocytes in silent cases of leprosy. These last are noteworthy for the fact that giant cells are also present both free in the dermis and associated with the nerves (Lever, I 96 I). Giant cells were found 
in man by Bergstad (1925) in a tumour infested with Demodex. Similar cells have been reported in cattle (Nemeseri and Szeky, I96I) and dogs (French, I964) as phagocytic for demodicids. In sections of skin infested with $D$. bovis which were recently examined in the laboratory of the senior author it appears that the chitinous exoskeleton is rapidly degraded even before degeneration of the internal cells of the mite. Definite lacunae are found in the exoskeletal wall sufficient in size to permit passage of bacteria to the cytoplasm of the giant cell. It would seem logical to presume that one should search here for a likely mechanism of bacterial inoculation. Infected mites could be the source for seeding giant cells with bacteria which could then multiply and spread from the giant cells to the surrounding tissue.

Fuss (1935) has discussed and depicted the marked polymorphism present in D. folliculorum. Specimens obtained by one of the authors of the present report (Pfaltzgraff) in North-east Nigeria are in several respects different from her account. The specimens from Nigeria are very similar to a human demodicid photographed but not discussed in taxonomic terms by Daniel et al. (1959). A recent paper (Akbulatova, i 964) states that two distinct subspecies of Demodex (D. f. longus and D. f. brevis) do occur in man.

With few exceptions due to the limitations of the host organism the studies on D. folliculorum are restricted to superficial examinations or study of biopsy material. Incidence surveys of cadavers (Gmeiner, I go8) have been few and have been carried out on carcasses available rather than on selected specimens with heavy demodicid infestations.

\section{Demodex spp.}

Since all $3^{8}$ species and subspecies (Nutting, I964) of the genus Demodex are remarkably alike in structure (see Hirst, I9I9) and niche requirements (Nutting, I965), it would seem profitable to examine facets of their biology which may be useful in studies of the Demodexleprosy association.

Of all demodicids, D. canis, of Canis familiaris is the most thoroughly known. It is also of more direct interest to our problem in that it shares a relationship with a bacterium. Although normally an inhabitant of the hair follicle it has been reported free in the dermis (Krulikovskii, I 878), in the lymph nodes (Canepa and da Grana, I94 I) and in most other viscera (Koutz, I957; French, r964). Canepa and daGrana found all stages of the mite life cycle in the lymph nodes which may indicate mite reproduction in this location. French stated that he could find no evidence of bacterial infection in the invaded lymph nodes. This is, however, not usually the case in the above mentioned dermal invasions which are associated with Staphylococcus albus. Apparently for this relationship no attempt has been made to locate bacteria within the mites. Bacteria and debris do adhere externally to $D$. canis as they move in vitro (Nutting, unpublished).

Several papers on D. canis purport to have discovered the mechanism of mite transference (Enigk, I949; French et al., I 964; Sako, I 965). This is reputedly not by an in utero route (see Unsworth, I 946 ) but rather by direct contact between bitch and pup during nursing. As suggested elsewhere (Nutting, I 965) the observational and experimental measures used by these investigators are not sufficiently critical to settle this issue.

Demodex caprae of Capra hircus have been found in papular lesions which may be either infected with or free of bacteria. Nutting ( 1950) reported that the contents, mites in all stages and an ether soluble product, of unruptured papules were commonly sterile. A suspect relationship in the goat between demodicids and lymphadenitis due to Staphylococcus spp. has been noted (Nutting, unpublished). Durant (1944, and personal communication) does not believe that a vector relationship is present in this association. The nodular lesions due to D. bovis in Bos taurus are said to be bacteria free (Nemeseri and Szeky, I 96 I) but as in French's account for D. canis no procedure for ascertaining this is given. Open nodular lesions are, however, often markedly suppurating in bovine demodectic mange. Lesions due to $D$. caprae represent the only assured source of large numbers of bacteria-free mites useful for vector studies.

Other than the dog, most laboratory animals so far examined in our University of Massachusetts laboratory (rabbit, guinea pig, rat, mouse, cat), have been either negative for demodicids or harboured very small mite 
populations. The Golden Hamster, Mesocricetus auratus, is an exception to this. In these a remarkable host-sex difference in parasite load is apparent with low populations in females and high populations in males (Nutting and Rauch, I 963). In the latter populations are occasionally so high that one or more mites may be found in nearly every hair follicle! Mites have not been found in internal tissues including the uterus or in foetuses (Nutting, I965). They have been recovered from the muzzle of suckling young at five days postpartum from mothers isolated in screened and sterilized cages (Nutting, r 950). The transference mechanism here seems to be by way of direct contact which in our studies proved Ioo per cent effective. Both species of Demodex in the hamster have been shown to be low grade pathogens which harvest cells of the epidermis (D. criceti) or of the follicular epithelium (D. aurati) (Nutting, I96I). As noted elsewhere (Nutting, I 964) the hamster is an ideal laboratory animal for work on demodicidiasis, and may under improved experimental conditions prove to be a choice subject for Demodex-leprosy studies.

As far as we can discover no attempt has been made to see whether populations of $D$. folliculorum fluctuate with time of year. Such changes have been reported for D. equi (Bennison, I 943) and $D$. bovis (Poliakov, I958). In these papers no experimental evidence is available to indicate the mechanism of population fluctuation. So far we have not been able to find any seasonal differences in D. aurati of the Golden Hamster under controlled laboratory conditions.

It should be mentioned here that other associations between demodicids and disease organisms have been suggested (Table I). We have yet to obtain any proof of a causal or cooperative connection between the mites and any disease entity. The work of Magnusson ( I 929) would seem to rule out a transfer role for D. bovis in hoof and mouth disease of cattle. As a working hypothesis demodicids should be held suspect as cooperative agents for any disease organism of the skin.

\section{Facets of Investigation}

From considerations of our knowledge of the biology of demodicid mites and the information on the association of $D$. folliculorum and leprosy certain fertile facets for investigation become apparent.

In laboratories associated with leprosaria it would be relatively easy to determine:

I. The incidence of $D$. folliculorum in leprosy patients versus 'controls' with attention to race, sex, drug regimen, age of the host and time of year.

2. Distribution of $D$. folliculorum in body areas and with respect to lesions of leprosy.

3. Whether or not M. leprae is found in the gut of D. folliculorum and confirmation of Spickett's observation on mite regurgitation.

4. If $D$. folliculorum commonly invades the dermis with especial attention to infections or degenerative changes in the skin.

5. Whether or not D. folliculorum is found in internal organs in man.

Other problems such as (I) if offspring delivered by Caesarean section with no history of nursing, which may negate Demodex transfer, develop

TA B L E I

Suspect cooperative relationships, with some degree of circumstantial evidence, between demodicids and disease organisms. *

\begin{tabular}{|c|c|c|c|}
\hline$\overline{\text { Disease }}$ & Demodicid & Authority & Date \\
\hline Acne & D. folliculorum & Simon & 1842 \\
\hline Pustulous mange & D. canis & Nunn & 1878 \\
\hline Blepharitis & D. folliculorum & Stcherbatchoff & 1903 \\
\hline Cancer & D. folliculorum & Borrel & I $909 \mathrm{~d}$ \\
\hline Red mange & D. canis & Gmeiner & I909 \\
\hline Hoof and mouth & D. bovis & Magnusson & 1929 \\
\hline Lymphadenitis (?) & D. caprae & Aynaud & I 93 I \\
\hline Nodulous mange & D. bovis & Momberg-Jorgensen & I 943 \\
\hline
\end{tabular}

*demodicids have been found in most skin diseases (see Gmeiner, I908). 
leprosy, and (2) if siblings from parents arthropod-free (i.e. other than Demodex) develop leprosy, could be resolved in long term studies.

Techniques for incidence studies of Demodex are simple and quickly performed. Mites are most readily recovered by examination of expressed sebaceous material from the facial naso-labial area. Lawrence ( I 9 i6) recommends expression with a small silver spoon. One could also use a comedo expressor although this is relatively tedious. Expressed material may be examined under the microscope (mites are under $0.5 \mathrm{~mm}$.) in the living condition by simply adding a drop of mineral oil. Permanent mounts can be made with Hoyer's solution (may be purchased from Wards Natural Science Establishment, Inc., Rochester, New York).

Biopsy or necropsy material should be fixed in 4 per cent formaldehyde. Sections, ro microns thick, should be cut from paraffin blocks and stained with hematoxylin and eosin (HE). By noting their morphological and tinctorial characteristics it also is possible now to examine for presumably viable $M$. leprae on, in, or around demodicids in situ (Rees and Valentine, r 962). A further refinement could be made using carefully washed and crushed demodicids injected into the foot pads of mice (Shepard, i 960).

Sako and Yamane ( I 962) found that internal structures, especially lymph nodes, which were adjacent to skin areas with the greatest parasite (D. canis) loads were most heavily infested. It would, therefore, appear most profitable to examine cervical or axillary lymph nodes in cadavers with high populations of $D$. folliculorum. Lymph nodes may either be digested in $\mathrm{KOH}$ (5 per cent), centrifuged and examined for mite exoskeletons or they may be sectioned ( $\mathrm{r} O \mu)$, stained (HE) and examined under the microscope.

Three ideal experimental animals are currently available for Demodex studies, the dog (Canis familiaris), Golden Hamster (Mesocricetus auratus) and the goat (Capra hircus), all of these with large populations of demodicids.

As noted above $D$. canis of the dog is easily obtained and should be re-investigated in order to resolve (I) the mechanism of mite transference, (2) the relationship of D. Canis to $S$. albus, and (3) the origin and function of giant cells. Such information could off er some valuable leads to studies of the leprosy problem.
The large populations of demodicids in the male Golden Hamster seem ideal for experimental purposes. Not only are two species present, $D$. criceti and $D$. aurati, but these inhabit distinct niches in the skin complex and are rather generally distributed over the body of the host. Furthermore, in $D$. aurati a differential position in the hair follicle is apparent for the stages of the mite life cycle. Since moderate infections of $M$. leprae have been obtained in the ear and testis of the hamster (Binford, I959) it would seem feasible to concentrate on this animal in studies of Demodex-leprosy relationships.

Hamsters are the present host of choice in screening drugs for the control of Demodex. So far no absolutely dependable measure is available to extirpate demodicids (see Koutz, I957; Nutting, I 964). Should such measures be devised massive prevention or treatment in endemic leprosy areas would answer our major question. Whether or not these mites transmit leprosy we still need an effective control procedure to prevent other demodectic diseases (see Nutting, I965).

Only in the goat do we have massive populations of demodicids (D. caprae) and these free of bacteria. The mites are found in large (to 32 $\mathrm{mm}$.) papules from which they are easily obtained by sterile puncture. The University of Massachusetts laboratory is currently attempting to find whether or not D. caprae will ingest bacteria and if these are transported or regurgitated. We are also concerned with the possible vector role of this species in lymphadenitis. Goat demodicids are also well suited for studies of the in vitro effects of chemicals which might be useful in control.

Giant cells are reputedly obtained from preparations of whole blood (Lewis, I 925). It would be instructive to examine with the Lewis technique the response of giant cells to demodicid mites, $M$. leprae and if possible the result of giant cell phagocytosis of Demodex which contain M. leprae. As has been shown for Trichomonas vaginalis (Honigberg, personal communication) in man, it seems plausible that $M$. leprae may subvert or destroy giant cells and thus be in a position to cause further damage to the host. It is certainly possible that destruction by phagocytosis of demodicids with an internal flora of bacteria would liberate these to the detriment 
of the phagocytic cell and subsequently to surrounding cells.

We should not overlook the suggestion of Gmeiner ( 1909) that demodicids may pave the way for the establishment of bacterial infections. Their activity which enlarges the lumen of the hair follicle and their ability to penetrate cell membranes may well be necessary features in leprosy invasion. Such factors coupled with the apparent ubiquity and sure mechanism of mite transfer from mother to young could account for the long term close contact which may be necessary for leprosy transmission. It could also explain the baffling and spotty results of such studies as Worth's (1960) where various rearing procedures for children from mothers with leprosy gave conflicting results for incidence of the disease.

Undoubtedly most of the suggestions above will be studied and the questions resolved in the next few years. A large laboratory could conceivably undertake the entire programme but it is more likely that independent workers will attack one or more of the separate facets of the problem. In either case it would seem profitable to pool our thinking and our experimental programmes along these lines so that cooperative timing or the benefits of new perspective may reduce the period necessary to determine whether or not demodicids are in any way causally related to human leprosy.

\section{Summary}

I. The literature on Demodex folliculorum pertinent to the problem of the possible transmission of Mycobacterium leprae and the initiation of leprosy is reviewed.

2. Information on other demodicids (esp. D. canis D. caprae and D. aurati) is also presented with an eye to its use in resolving the suspect relationship of $D$. folliculorum and $M$. leprae.

3. A number of suggestions are made which would materially aid an attempt to settle the problem of whether or not there is any causal relationship between D. folliculorum and leprosy.

\section{A G K N OWLEDGEMENT}

This paper is based upon a preliminary draft by William B. Nutting which was read and discussed at the Public Health Service Hospital, Carville, La. on March I8, I965. Criticism and additions at this meeting were provided by Drs E. Johnwick and J. Trautman (Carville) and Drs G. Thurber, E. Thurman and J. Swartzwelder (Louisiana State University School of Medicine). The authors extend their sincere thanks to these investigators for their help.

Research results reported from the University of Massachusetts laboratory were obtained under a USPHS Grant E-562 and NSF Grants G-2332 I and GB-35 I 6 .

This paper has been given clearance by the Bureau of Medical Services, United States Government.

\section{IN MEMORIAM}

Dr Edgar B. Johnwick, Medical Officer in Charge, Public Health Service Hospital, Carville, La. passed away on October I 4,1965 . His pleasant, helpful and catalytic personality will be missed deeply by all of his friends and by his associates in problems of leprosy.

\section{REFERENCES}

akbulatova, L. кн. (1964) Demodicidosis of man. Vestnik Dermat. $i$ Venerol,. 38 : $34-42$.

Aynaud, N. (I93 I) Kystes a Demodex, kystes sebaces et abcès du mouton. Ann. Inst. Pasteur, Paris, 46 : 306-3 9. BeERman, H. and stokes, J. (I934) Rosacea complex and Demodex folliculorum. Arch. Dermat. Syph., Chicago, 29 : 874-884.

BENNISON, J. (I943) Demodicosis of horses with particular reference to equine members of the genus Demodex. Jour. Roy. Army Vet. Corps (Great Britain), r4 : 34-49 and 66-73.

BergStAD, E. (1925) Fall von Hautveranderung hervorgerufen durch Demodex folliculorum. Acta Derm. Venereol., 6 : 329-333.

Bertarelli, E. and paranhos, u. (igio) Sulla diffusione della lebbra mediante gli acaridi. Gior. Ital. Mal. Ven., 51 : 902-904.

BINFORD, C. H. (I959) Histiocytic granulomatous mycobacterial lesions produced in the Golden Hamster (Cricetus auratus) inoculated with human leprosy. Lab. Invest., 8 : $90 \mathrm{I}-924$.

borrel, A. (1908) Demodex et infections cutanées. Comp Rend. Soc. Biol., Paris, 65 : 596-597.

- (r goga) Lèpre et Demodex. Compt. Rend. Acad. Sc., Paris, $14^{8}$ : $50-51$.

- (1 gogb) Acariens et lèpre. Ann. Inst. Pasteur, Paris, 23 : I $25-128$.

- (r 9o9c) Lèpre et Demodex. Naturaliste, 31 : 39-40.

- (rgogd) Acariens et cancers (avec la collaboration de Gastinel et Gorescu). Bull. Ass. Fran. Etude Cancer, 2 : 29-53.

CANEPA, E. and DAGRANA, A. (I94I) La presencia del Demodex folliculorum Owen en los ganglios linfaticos de perros demodecticos. Rev. Fac. Agronom. y Vet., Buenos Aires, 9 : I o9-I I 4. 
DANiel, M., BOzDEch, v. and moucka, C. (I959) Vyskyt trudnika tukoveho (Demodex folliculorum Owen i 843) u lidi a jeho epidemiologie. Ceskosluv. Epidemiol. Microbiol., Immunol., 8 : 52-6o.

DUNGAL, N. (I96I) Is leprosy transmitted by arthropods? Leprosy Review 32 : 28-35.

DURANT, A. ( 1944 ) Demodectis mange of the milk goat. Vet. Med., 39 : 268-270.

ENIGK, K. (1949) Zur Kenntnis der Demodexraude des Hundes. Zentralbl. Bakteriol. I Abt. Orig., r53 : 76-9o.

FRENCH, F. E. (I964) Demodex canis in canine tissues. Cornell Vet., 54: 271-290.

- RAUn, E. s. and BAKER, D. L. (I964) Transmission of Demodex canis Leydig to pups. Iowa State 7. of Sci., 38 : $29 \mathrm{I}-298$.

Fuss, F. (1933) Parasitic life of Demodex folliculorum hominis. Ann. Dermat. Syph., 4 : 1 053-1 062.

- (1935) Le cycle évolutif du Demodex folliculorum hominis vu par la microphotographie. Ann. Dermat. Syph., 6 : 326-33 I.

gmeiner, F. (igo8) Demodex folliculorum des Menschen und der Tiere. Arch.f. Dermat. u. Syph., 92 : 25-95.

- (r9o9) Demodex folliculorum des Menschen und der Tiere. Berl. Tierarztl. Wschnschr., 25 : 695-700.

hirst, s. (r9i9) Studies on Acari I. The genus Demodex Owen. Brit. Museum, Nat. Hist., London.

honigberg, B. M. Personal Communication. University of Massachusetts, Amherst.

Khanolkar, v. R. (I 959) Pathology of leprosy. Chapt. 7 LEPROSY IN THEORY AND PRAGTICE. Bristol,'Wright \& Sons.

koutz, F. (I957) Demodex folliculorum studies VI. The internal phase of canine demodectic mange. 7. Am. Vet. Med. Ass., r31 : 45-48.

KRULiKovskil, s. (1878) Change in cutaneous and subcutaneous tissues caused by Demodex folliculorum canis in the dog from a clinical and anatomo-pathological standpoint. Arkh. Vet. Nauk, S. Peterburg, 8 : 1 $35^{-1} 5^{0}$ and $\mathrm{I}_{5} \mathrm{I}-\mathrm{I} 9 \mathrm{O}$.

LAWRENCE, H. (I9I6) On a skin eruption associated with the presence of great numbers of Demodex folliculorum. Med. 7. Australia, 2 : 555-556.

Lefebvre, м. (1910) Researches on Acarids among lepers. Philippine 7. Sc., Sect. B, Med. Sc., 5 : 463-474.

LEVER, W. F. (I96I) histopathology of THE Skin. (3rd edition) J. B. Lippincott, Philadelphia.

LEWIS, W. H. (I925) The transformation of mononuclear blood cells into macrophages, epithelioid cells, and giant cells. Harvey Society Lecture, New York, 21 : 77-1 12. magnusson, H. (1929) Ett fall av Acarus (Demodex folliculorum) hos ko jamte forsok rorande Acarus sasom mellanvard vid mul- och klovsjuka. Skand. Vet. Tidskr., r9 : 94- IOO.

MAJOCGHi, D. (I914) Il Demodex folliculorum sulla pelle dei leprosi. Bologna Rend. Acc. Sc., 18 : 107-1 08.

momberg-Jorgensen, H. (i 943 ) Et Tilfaelde af Demodikose hos Kvaeg. Maanedsskr. Dyrl., 55 : I o9-I I 5.

NeVeu-lemaire, M. (I 938) TRAite D'entomologie mediCale et veterinaire. Xxvil, i 339 pp., Paris.

NEMESERI, L. and SZeKy, A. (I96I) Demodicosis in cattle. Acta Vet. Acad. Sci., Hungary, II : 209-22 I.

Nicholas, L. D. (1943) Demodex folliculorum. I ts incidence in routine histologic study of the skin. Arch. Dermat. Syph., Chicago, 47 : 793-796.
NUNN, J. A. ( 1878 ) On some of the skin diseases of the dog that are commonly known as 'mange'. Vet. 7. and Ann. Comp. Path., 6 : 82-84 and I 70-1 82.

nutring, w. B. ( I950) Studies on the genus Demodex Owen (Acari, Demodicoidea, Demodicidae). Thesis (Ph. D.) Cornell University.

- (I96I) Demodex aurati sp. nov. and D. criceti, ectoparasites of the Golden Hamster (Mesocricetus auratus). Parasitol., 51 : $5^{1} 5^{-522}$.

- (r964) Demodicidae - Status and Prognostics. Acarologia, 6 : 44 I-454.

- (1965) Host-Parasite Relations : Demodicidae. Acarologia, $7: 30 \mathrm{I}-3 \mathrm{I} 7$.

- and RAUCH, H. (1963) Distribution of Demodex aurati in the host (Mesocricetus auratus) skin complex. 7. Parasitol., 49 : 323-329.

- and Beerman, H. (1965) A typical giant cells in Antechinus stuartii due to demodicid mites. F. Invest. Dermatol., 45 : 504-509.

Poliakov, D. K. (1958) Seasonal dynamics of Demodectes bovis, and experiment in treatment of invasion by it. Trudy Vsesoiuz. Nauchno-Issled. Inst. Vet. San. $i$ Ekto-parazitol., 13 : 107-1 16.

REES, R. J. and VAlEntine, R. C. (1962) The appearance of dead leprosy bacilli by light and electron microscopy. Internat. 7. Leprosy, 30 : I-9.

sAKо, s. (1965) Studies on canine demodicosis with special reference to opportunity of infection from a view point of prevention. 7. Japan. Vet. Med. Assoc., 18 : 6-1 4.

- and yamane, O. (1962) Studies on the canine demodicosis II. The significance of presence of the parasite in lymphatic glands of affected dogs. Jap. Jour. Parasitol., I I : 93-I OO.

SERrA, A. ( $1912^{*}$ ) Lo stato attuale della lepra in Sardegna. Cagliari, Tip. Dessi.

- (192 I) Lepra e Demodex folliculorum. Pathologica (305) 13 : $36 \mathrm{I}-368$.

Serra, G. (1942) Contributo allo studio dell-infezione cutanea da Demodex. Ann. Patol. Trop. e Parassitol., 3 : 257-270.

SHEPARD, c. C. (1960) The experimental disease that follows the injection of human leprosy bacilli into the footpads of mice. 7. Exp. Med., I12 : 445-454.

simON, D. ( I 842) Ueber eine in den kranken und normalen Haarsacken des Menschen lebende Milbe. Arch. Anat., Physiol. u Wissensch. Med., pp. 2 1 8-237.

spickett, s. G. (ig6ra) Studies on Demodex folliculorum Simon (1842) I. Life History. Parasitol., 51 : 18 I-192. - (I96rb) A preliminary note on Demodex folliculorum Simon (1 842) as possible vector of leprosy. Leprosy Rev., 32 : 263-268.

stcherbatchoff. (1903) Le Demodex folliculorum Simon dans les follicles ciliares de l'homme. Thèse (Lausanne).

unsworth, K. (1946) Studies on the clinical and parasitological aspects of canine demodectis mange. 7. Comp. Path. Therap., 56 : 1 14-1 27.

worth, R. м. (1960) Leprosy in children born at Kalaupapa. Hawaii Med. 7., 19 : 403-406.

yoкауама, к. (I94I) Acne due to Demodex folliculorum. 7ap. 7. Dermat. Urol., 49 : 24.

*from résumé in Serra, 192 I. 